\title{
Alternative agrifood projects in communities of color: A civic engagement perspective
}

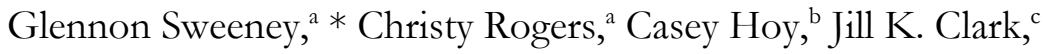 \\ Kareem Usher, ${ }^{\mathrm{d}}$ Kip Holley, ${ }^{\mathrm{a}}$ and Colleen Spees ${ }^{\mathrm{e}}$ \\ The Ohio State University
}

Submitted June 15, 2015 / Published online July 23, 2015

Citation: Sweeney, G., Rogers, C., Hoy, C., Clark, J. K., Usher, K., Holley, K., \& Spees, C. (2015). Alternative agrifood projects in communities of color: A civic engagement perspective. Journal of Agriculture, Food Systems, and Community Development, 5(4), 69-75. http://dx.doi.org/10.5304/jafscd.2015.054.005

Copyright (C 2015 by New Leaf Associates, Inc.

\begin{abstract}
In this commentary we very briefly highlight farming- and land-related historical injustices impacting African Americans, and outline useful ways for racially diverse food justice organizations, activists, and academics to collaborate on placebased interventions in an equitable and inclusive way. Place-based strategies to address inequity in the food system must begin with an equitable and

\footnotetext{
a * Glennon Sweeney (Corresponding author), Christy Rogers, and Kip Holley: Kirwan Institute for the Study of Race and Ethnicity at the Ohio State University; 33 West $11^{\text {th }}$ Avenue; Columbus, Ohio 43201 USA; sweeney.270@,osu.edu; christyrogers441@gmail.com; kipholley.kirwaninstitute@gmail.com

b Casey Hoy, Professor of Entomology, College of Food, Agriculture, and Environmental Sciences, The Ohio State University, Wooster Campus; 1680 Madison Avenue; Wooster, Ohio 44691 USA; hoy.1@osu.edu

c Jill K. Clark, Assistant Professor of Public Affairs, John Glenn College of Public Affairs, The Ohio State University; 1810 College Road; Columbus, Ohio 43210 USA; clark.1099@osu.edu
}

inclusive environment within which residents can engage in developing solutions. Equitable and inclusive civic engagement can build capacity, trust, and empowerment in marginalized communities, creating an environment where communities can enact transformative local food system change using their own resources. Transformative change is change that occurs at the very core of ourselves as individuals and in our communities. Such change requires us to reexamine our long-standing customs, assumptions, beliefs, and institutional

\footnotetext{
d Kareem Usher, Post Doctoral Researcher, City and Regional Planning, Knowlton School of Architecture, Ohio State University; and Kirwan Institute for the Study of Race and Ethnicity, The Ohio State University; 275 West Woodruff Avenue; Columbus, Ohio 43210 USA; usher.21@,osu.edu

e Colleen Spees, Assistant Professor, Medical Dietetics, The Ohio State University College of Medicine; 453 West $10^{\text {th }}$ Avenue; Columbus, Ohio 43210 USA; colleen.spees@osumc.edu
}

Authors' note: With special thanks and acknowledgement to Michelle Kaiser, Assistant Professor of Social Work, Ohio State University College of Social Work. 
practices, moving community conversations towards those that build relationships, foster mutual accountability, and strive for respectful understanding among neighbors and neighborhoods. Transformative change doesn't come easily. However, practicing equitable engagement can help build capacity for sustaining change. Alternative food movement scholars and activists can lift up and build on community assets, but to do so requires historical understanding, recognition of individual and community strengths, and work to build long-term relationships of trust.

\section{Keywords}

alternative agrifood movement, civic engagement, race, farming

$\mathrm{I}^{\mathrm{n}}$ ndustrialization and globalization of the food system have wrought profound changes in local food environments with respect to cost, availability, and variety. And while one result is that food is a small percentage of household expense in the U.S. (making up $9.8 \%$ of the average budget in 2013) (USDA ERS, n.d.), the cost of a balanced and health-promoting diet depends on where one lives (Hilbert, Evans-Cowley, Reece, Rogers, Ake, $\&$ Hoy, 2014). Thus the percentage of income needed to maintain a balanced diet might vary widely. Many urban neighborhoods with little internal wealth or external investment lack fullservice grocery stores, and many of the residents of such neighborhoods lack adequate transportation to access affordable, healthy food (McClintock, 2011; Odoms-Young, Zenk, Karpyn, Ayala, \& Gittelsohn, 2012). ${ }^{1}$ Often families living in these communities must travel longer distances than those in other neighborhoods to access full-service grocery stores, or are limited to shopping nearby at

\footnotetext{
${ }^{1}$ For the purposes of this short commentary, the authors have chosen to focus on urban food environments and African American history. We recognize that rural food environments and the exploitation and marginalization of other racial and ethnic populations are equally significant, and that they share some of the social and political drivers of inequality that can characterize African American neighborhoods lacking full access to healthy foods. We look forward to collaborating on a longer article that delves more deeply into the fuller story of racialized land loss, inequality, and food injustice.
}

smaller stores. These smaller local stores may improve selection in neighborhoods which lack full-service grocery stores, but often have higher prices and/or reduced quality (Raja, Ma, \& Yadav, 2008). At the same time, rates of preventable diseases, infant mortality, and other public health concerns are much higher in neighborhoods with inequitable healthy food access (Heynen, Kurtz, \& Trauger, 2012; Odoms-Young et al., 2012).

The alternative agrifood movement (AAM) has broadly positioned itself as an alternative to the global, industrial food system (Friedland, 2008). Some AAM members promote local, organic and identity-preserved foods as important components of personal, public, and environmental health (Harper, 2011). While this movement is directed at all food consumers (regardless of income), accessing healthier food is often a matter of consumer choice for affluent consumers. But within many economically distressed urban neighborhoods, accessing healthy food can be very challenging. AAM initiatives aiming to bring healthy food to low-income communities have been met, on occasion, with indifference or even open hostility. Some scholars attribute this phenomenon to a lack of understanding of, and sensitivity to, the historical relationship between Whites, African Americans, the land, and food (Green, Green, \& Kleiner, 2011) as well as the perceived "elite" status of the AAM (Cadieux \& Slocum, 2015; Guthman, 2007, 2011; Harper, 2011).

In this commentary, we very briefly highlight farming- and land-related historical injustices impacting African Americans and outline useful ways for racially diverse organizations, activists, and academics to collaborate with urban communities of color in an equitable and inclusive way. Equitable and inclusive civic engagement can build capacity, trust, and empowerment in marginalized communities, creating an environment where communities can enact transformative local food system change using their own resources.

The historical legacy of farming in America, and in particular in the American South, is formidable. Indeed, agricultural structures and systems, beginning with slavery and extending to tenancy, sharecropping, and the crop-lien system, underpinned land-owning Whites' subjugation and 
control over African American (and poor White) people and farmers in the South throughout our early history (Green et al., 2011; Massey \& Denton, 1993). The corresponding legacy of these structures and systems are reflected in both African American cultural attitudes toward farming, and the underrepresentation of African Americans in the American agricultural sector (Green et al., 2011; Guthman, 2011).

African Americans remain underrepresented in farm ownership today. Particularly during the second half of the $20^{\text {th }}$ century, smaller farms struggled to keep up with the cost of mechanization, more complex inputs (e.g., fertilizers, pesticides, new cultivars), and the need to purchase additional acreage to capture ever-greater economies of scale. This struggle to compete at increasing scales was systematically greater for African American farmers than for White farmers (Hinson \& Robinson, 2008). Over the last century, the country experienced an estimated 98 percent loss in African American farm operations and a 66 percent loss in White farm operations, all while the largest (and typically White-owned) farming operations grew even larger (Green et al., 2011). Although African American farms tended to be smaller than White farms in terms of acres and sales, Wood and Gilbert (2000) found that when controlling for scale of operation based on gross sales, African American farmers were still disproportionately reflected in these farm loss trends.

Institutional racism at various levels of government disproportionately created barriers to land ownership and farm growth for African American farmers. In particular, African American famers were not fairly awarded USDA loans. In 1982, a U.S. Civil Rights Commission found that in 1980 and 1981 local offices of the USDA loaned less than two percent of all farm ownership loan amounts and less than three percent of all farm operating loan amounts to African American farmers (Hinson \& Robinson, 2008). As a result, the largest class action lawsuit in U.S. history, known as the Pigford case, was filed against the U.S. Department of Agriculture in the late 1990s and was settled in 2000, resulting in ongoing claims processing for African American, Hispanic, Native
American, and women ranchers and farmers (Hinson \& Robinson, 2008). ${ }^{2}$

The loss of farm land ownership pushed many African Americans into urban spaces, migrations reflected in many central cities that are now home to large African American populations (Green et al., 2011; Massey \& Denton, 1993). Unjust practices of urban housing and neighborhood exclusion such as redlining, block-busting, restrictive covenants, and steering segregated neighborhoods by both race and class. This was followed by consistently inequitable and reduced investment in minority neighborhoods by city governments and private interests throughout the U.S. (Gotham, 1998; Highsmith, 2009; Logan \& Molotch, 2007; Massey \& Denton, 1993; Schildt, 2011). Racism, exclusion, and disinvestment led to a downward spiral in opportunity that is reflected in high unemployment rates, high vacancy rates, high rates of preventable health problems, and failing local economies (Dreier, Mollenkopf, \& Swanstrom, 2004; Massey \& Denton, 1993; Wilson, 1996). As local economies failed and access to necessary resources like credit and insurance declined, many businesses (not just food-related businesses) left these neighborhoods (Massey \& Denton, 1993). The combined effects of these practices made the acquisition of land for any use-residential, commercial, farming - challenging for the African American community (Gotham, 1998; Highsmith, 2009; Logan \& Molotch, 2007; Massey \& Denton, 1993; Schildt, 2011). Thus the U.S. food system remains inequitable, long after overt racism has subsided (Alkon \& Agyeman, 2011).

Reconnecting people with food and farming is often seen as a means of addressing the vast, often racialized economic and health-related disparities in the food system. The AAM often recognizes and critiques the inequities and injudicious policies inherent in the modern food system (Alkon \& Agyeman, 2011; Cadieux \& Slocum, 2015; Guthman, 2007, 2008, 2011; Harper, 2011). Yet prescriptions for small-scale urban agriculture and diet-related behavior do not examine the root causes of the injustices they are meant to address (Guthman, 2007, 2011). And because of the rich

${ }^{2}$ See http://www.outreach.usda.gov/settlements.htm 
history of farming in African and African American culture (despite the multiple barriers to land ownership and repeated attempts to exploit African American labor in the U.S.), many African Americans find it offensive when Whites travel to urban neighborhoods and offer to "teach" them how to garden (Guthman, 2008). Though well-intentioned, AAM proponents may be offering a short-term solution when they could contribute powerfully to a sustainable, long-term one by investing in community engagement for collective empowerment and transformative change.

The Kirwan Institute for the Study of Race and Ethnicity (Kirwan) has worked with lowincome communities of color to build capacity for transformative change for over a decade, and has recently summarized a set of principles for equitable and inclusive civic engagement as a result of this work (Holley, in press). ${ }^{3}$ The following abridged summary of principles for equitable engagement and transformative change is taken from this work in the hopes that it can be helpful to the important food justice activism and scholarship across the country.

Transformative change is change that occurs at the very core of ourselves as individuals and our communities. Such change requires us to reexamine our long-standing customs, assumptions, beliefs, and institutional practices, moving community conversations toward those that build relationships, foster mutual accountability, and strive for respectful understanding among neighbors and neighborhoods. Transformative change requires a shift in how we measure engagement outcomes (changes achieved), and

\footnotetext{
${ }^{3}$ Much of what we have learned over the last 10 years has been in conversation and co-learning with our community partners. This learning, grounded in the writings of Peter Block's Civic Engagement and the Restoration of Community and The Abundant Community, and Eric Uslaner's Civic Engagement in America, is detailed in "Growing Together for a Sustainable Future: Strategies and Best Practices for Engaging with Disadvantaged Communities on Issues of Sustainable Development and Regional Planning,"

"Expanding Democracy: A Framework for Bolstering Civic Power and Rebuilding Communities," and "Shining the Light: A Practical Guide to Co-Creating Healthy Communities," all available at http://kirwaninstitute.osu.edu/
}

perhaps even more importantly, a change in how we work within communities (changes in how engagement occurs).

The principles that can serve communities well in the context of the AAM include facing the effects of race, history, and power inequities as a community, embracing the gifts of diverse communities, and building trust and commitment in the community engagement environment. Additional principles include honoring dissent and protests as expressions of civic voice, practicing radical community hospitality, and adapting to community changes.

The historical legacy of the relationship of African Americans and food production in America is a particularly painful one. It is a history rife with profound injustice and inequity. The cumulative impacts of rural and urban disempowerment, displacement, and exclusion has resulted in long-standing urban and rural inequities. Yet this history and its consequences should be acknowledged and understood-not ignoredtoday. All of our communities, however well or poorly they have been treated, are important places in people's lives. Our communities are places where our personal histories unfold. Embedded in each place is its own history, which is a part of each community member's personal narrative as well. Too often the people who make up the neighborhoods, and their stories, are ignored or forgotten. Transformative change in the food system can begin by creating empathy and opportunities for people within communities to explore their histories together, leading to a greater understanding of how history shapes our personal and community narratives as well as the inequities we experience.

Embracing the gifts of diverse communities is also essential. Every community has assets, and many can be found in the skills and talents of the individuals living in the community. These gifts can manifest themselves through the abilities, competencies, and unique experiences of each member of the community. For example, some community members may possess artistic skills that can be put to use promoting community events. Others may possess leadership skills, language skills, a gift for working with children, or have connections to 
other organizations that wish to partner. Flora and Flora (1996) describe such skills and talents as buman capital and such relational connections as social capital, both forms of community capitals that also include the natural (in the land), built (grocery stores, for example) and financial forms of capital. When a community is aware of and embraces all of its capitals, it can draw from these collective assets when confronting challenges. It is also through realizing and celebrating the gifts inherent in its people that further social capital is built, and it is through such relationships that the bedrock of our communities are formed.

Transformative change cannot occur without empowerment. Building trust and commitment is a necessary step toward empowering communities to create transformative change. A culture of distrust often exists in impoverished communities as a result of years of disinvestment, broken promises, and structurally segregative policies (Gotham, 1998; Highsmith, 2009; Logan \& Molotch, 2007; Massey \& Denton, 1993; Schildt, 2011). Suspicion of new public and private initiatives is a common result of this sad experience, frequently culminating in civic disengagement. But trust can be built by forging relationships based on mutual support. Trust can also be fostered by making and keeping promises. Building trust in communities where high levels of doubt, suspicion, and disengagement are present requires consistency and long-term commitment by organizations and individuals. Further, building trust means building empowerment; that is, it means promoting and supporting leadership in community members and recognizing that local community leaders are essential to achieving transformative change. Finally, mutual accountability is vital to community engagement; not only can it create more complete and honest communication between community stakeholders, but also encourages shared responsibility and shared learning, which are essential aspects of building trust. Through mutual accountability, communities can ensure that the agreements and plans created to strengthen the community today will be able to withstand political and social changes tomorrow.

Examples of the principles of equitable and inclusive civic engagement in action can be found in Kirwan's work in its home community of Columbus, Ohio. "More Than My Brother's Keeper" (MTMBK) is a program run in partnership with key community anchor institutions, including the local children's hospital and a neighborhood community-development collaborative. The program supports at-risk African American male youth (ages 10 to 14) and their families residing on the south side of the city. MTMBK incorporates both experiential learning and intensive mentoring to help kids discover their own assets and build relationships of mutual trust with each other and with the Kirwan (and other partner) staff and community members. While Kirwan leads conversations among community stakeholders to address issues of affordable and safe housing, food access, and healthy and diverse "third places,"4 the needs and strengths of the boys and their families are the key drivers of the program's adaptive design. This collaborative process has resulted in the creation of a neighborhood leadership academy, a plan for addressing housing needs in the neighborhood, a community focus on supporting vibrant third places, and a plan to address issues of food access and insecurity, particularly with the community's children.

Place-based strategies to address inequity in the food system must begin with an equitable and inclusive environment, within which the people can engage in developing solutions. Change doesn't come easily. However, practicing equitable and inclusive civic engagement that recognizes our collective, and often painful, historical legacy can help equip community members and collaborators with the tools required to build capacity for sustaining change. Alternative food movement scholars and activists can lift up and build on community assets, but to do so requires historical understanding, recognition of individual and community strengths, and working to build longterm relationships of trust.

\footnotetext{
${ }^{4}$ Third spaces are community meeting places that are neither work nor home. See Ray Oldenburg, The Great Good Place: Cafes, Coffee Shops, Bookstores, Bars, Hair Salons, and Other Hangouts at the Heart of a Community, 1999.
} 


\section{References}

Alkon, A. H., \& Agyeman, J. (2011). Cultivating food justice: Race, class, and sustainability. Cambridge, Massachusetts: MIT Press.

Cadieux, K. V., \& Slocum, R. (2015). What does it mean to do food justice? Journal of Political Ecology, 22, 1-26. http://ipe.library.arizona.edu/Volume 22/Volume 22.html

Dreier, P., Mollenkopf, J., \& Swanstrom, T. (2004). Place matters: Metropolitics for the twenty-first century ( $2^{\text {nd }} \mathrm{ed}$.). Kansas: University Press of Kansas.

Flora, C. B., \& Flora, J. L. (1996). Creating social capital. In W. Vitek \& W. Jackson (Eds.), Rooted in the land: Essays on community and place (pp. 217-225). New Haven, Connecticut: Yale University Press.

Friedland, W. H. (2008). "Chasms" in agrifood systems: Rethinking how we can contribute. Agriculture and Human Values, 25(2), 197-201. http://dx.doi.org/10.1007/s10460-008-9116-2

Gotham, K. F. (1998). Blind faith in the free market: Urban poverty, residential segregation, and federal housing retrenchment, 1970-1995. Sociological Inquiry, 68(1), 1-31. http://dx.doi.org/10.1111/ j.1475-682X.1998.tb00452.x

Green, J. J., Green, E. M., \& Kleiner, A. M. (2011). From the past to the present: Agricultural development and black farmers in the American South. In A. H. Alkon \& J. Agyeman (Eds.), Cultivating food justice: Race, class, and sustainability (pp. 47-64). Cambridge, Massachusetts: MIT Press.

Guthman, J. (2007). Can't stomach it: How Michael Pollan et al. made me want to eat Cheetos. Gastronomica: The Journal of Food and Culture, 7(3), 7579. http:/ /www.gastronomica.org/summer-2007/

Guthman, J. (2008). Bringing good food to others: Investigating the subjects of alternative food practice. Cultural Geographies, 15(4), 431-447. http://dx.doi.org/10.1177/1474474008094315

Guthman, J. (2011) "If they only knew": The unbearable whiteness of alternative food. In A. H. Alkon \& J. Agyeman (Eds.), Cultivating food justice: Race, class, and sustainability (pp. 263-282). Cambridge, Massachusetts: MIT Press.

Harper, A. B. (2011). Vegans of color, racialized embodiment, and problematics of the "exotic." In A. H. Alkon \& J. Agyeman (Eds.), Cultivating food justice: Race, class, and sustainability (pp. 221-238). Cambridge, Massachusetts: MIT Press.
Heynen, N., Kurtz, H. E., \& Trauger, A. (2012). Food justice, hunger and the city. Geography Compass, 6(5), 304-311. http://dx.doi.org/10.1111/j.1749$\underline{8198.2012 .00486 . x}$

Highsmith, A. R. (2009). Demolition means progress: Urban renewal, local politics, and state-sanctioned ghetto formation in Flint, Michigan. Journal of Urban History, 35(3), 348-368. http://dx.doi.org/10.1177/0096144208330403

Hilbert, N., Evans-Cowley, J., Reece, J., Rogers, C., Ake, W., \& Hoy, C. (2014). Mapping the cost of a balanced diet, as a function of travel time and food price. Journal of Agriculture, Food Systems, and Community Development, 5(1), 105-127. http://dx.doi.org/10.5304/jafscd.2014.051.010

Hinson, W. R., \& Robinson, E. (2008). 'We didn't get nothing": The plight of black farmers. Journal of African American Studies 12(3), 283-302. http://dx.doi.org/10.1007/s12111-008-9046-5

Holley, D. (in press). Principles for equitable and inclusive civic engagement. Columbus, Ohio: Kirwan Institute

Logan, J. R., \& Molotch, H. L. (2007). Urban fortunes: The political economy of place (20 ${ }^{\text {th }}$ anniversary ed.). Berkeley, California: University of California Press.

Massey, D. S., \& Denton, N. A. (1993). American apartheid: Segregation and the making of the underclass. Cambridge, Massachusetts: Harvard University Press.

McClintock, N. (2011). From industrial garden to food desert: Demarcated devaluation in the Flatlands of Oakland, California. In A. H. Alkon \& J. Agyeman (Eds.), Cultivating food justice: Race, class, and sustainability (pp. 89-120). Cambridge, Massachusetts: MIT Press.

Odoms-Young, A. M., Zenk, S. N., Karpyn, A., Ayala, G. X., \& Gittelsohn, J. (2012). Obesity and the food environment among minority groups. Economy and Environment, 1(3), 141-151. http://dx.doi.org/10.1007/s13679-012-0023-x

Raja, S., Ma, C., \& Yadav, P. (2008). Beyond food deserts: Measuring and mapping racial disparities in neighborhood food environments. Journal of Planning Education and Research, 27(4), 469-482. http://jpe.sagepub.com/content/27/4/469.full.pdf

Schildt, C. (2011). The struggle of memory against forgetting: Insurgent histories and the development of a new suburban praxis. Berkeley Planning Journal, 24(1), 141-149. https://escholarship.org/uc/ucb crp_bpj?volume $=24 ;$ issue $=1$ 
U.S. Department of Agriculture, Economic Research Service [USDA, ERS]. (n.d.). Food expenditures [Data sets]. Retrieved June 15, 2015, from

http://www.ers.usda.gov/data-products/foodexpenditures.aspx\#26634

Wilson, W. J. (1996). When work disappears: The world of the new urban poor. New York: Knopf.
Wood, S. D., \& Gilbert, J. (2000). Returning African American farmers to the land: Recent trends and a policy rationale. The Review of Black Political Economy, 27(4), 43-64.

http://dx.doi.org/10.1007/BF02717262 